\title{
... And, Above All, Friendship: Thanks, George!
}

\section{Beatriz J. Rizk}

I came into contact with George early in my career, during the late 70 s, beginning of the 80 s. I was involved with Teatro 4, in New York City, sort of a street theatre troupe (only because we had no place to perform), however very engaged politically in whatever we thought was highly "politically incorrect" at the time (and there was plenty). It was George, already a larger than life character for all of us, who asked me to write a report for the Latin American Theatre Review on a New Theatre Workshop which took place in Cuba in 1983. Diligently, and with excessive enthusiasm, I wrote it and sent it to him. He did not forward it to any editor for reviews - because I'm sure it would have been instantly rejected; instead, he crossed out all the extra verbose adjectival allusions, revolutionary and otherwise, and published it. It was my first printed piece, and possibly the most important lesson I have received early on which has accompanied me throughout my writing trajectory; I always go back to my writings, armed with a red pencil, and cross out whatever I think George would disqualify as being too enthusiastic, or exaggerated, or even excessive in ideological terms.

My meetings with George took place all over the Americas and Europe, wherever festivals and conferences on Latin American theatre were held over the last three decades, including his own conferences which I devoutly attended. Some of our encounters that I vividly remember include the past-midnight suppers at Pepito's in Buenos Aires where we usually dropped in after seeing possibly two, even three, performances a night; or the long walks though Cádiz between performances; or in Asunción where our dear late friend Edda de los Ríos invented a symposium to bring us to her homeland; and, of course, his visit to Miami, with Eleanor, where we finally had the opportunity to reciprocate his generous hospitality at his memorable "pachangas" in Lawrence. 
His passion for theatre was contagious (not that I needed encouragement) and we were both Latin Americanists, in the widest sense of the word, which meant never-ending conversations on the most varied spectrum of topics we could come across in our "theatrical" findings. George knew what I was cooking throughout the years; the same way he kept sending me his essays and books, I shared my work with him. He published another eleven essays and reports of mine throughout the years, and when he asked me if I would consider publishing my coming book with his recently-founded publishing house, of course I didn't hesitate to answer affirmatively. Little did I know that what was supposed to be a medium-size text would turn into two 400-pages volumes at his request. We spent the last two years of his life writing to each other frequently as he took it upon himself to edit the books, and he knew we did not have much time left on our side. The more I wrote, the more he pressured me to continue writing. Needless to say his comments, suggestions, and inside views concerning every topic related to theatre immensely enriched my work throughout my career. I will be forever grateful for his generosity, guidance, and, above all, friendship.

Key Biscayne, FL 